\title{
Covid-19 pandemic and the prospects of education in South Africa
}

\author{
Lesley Le Grange ${ }^{1}$
}

Accepted: 23 September 2020 / Published online: 19 October 2020

(C) UNESCO IBE 2020

\begin{abstract}
The Covid-19 pandemic has caused havoc in the world, radically changing our lives and raising new and old questions, both existential and educational. This pandemic has revealed the underbelly of South African society in general and its education system more specifically - it has laid bare the gross inequalities that are the legacies of apartheid and the consequences of neoliberal capitalism. Drawing on ideas articulated in the four introductory chapters of the International Handbook of Curriculum Research, edited by William Pinar in 2014, this article discusses Covid-19 and the prospects of education in South Africa. The article shows how understanding the wisdom of indigenous traditions along with the moral dimensions of education, race, and the new technologies of surveillance, neoliberalism, and education can provide a nuanced awareness of the nature of the Covid-19 pandemic. It then explores the implications of such insights for the field of curriculum studies and, where relevant, for the school curriculum. It concludes by showing how these broad themes intersect and gel around the notion of Ubuntu-currere.
\end{abstract}

Keywords Covid-19 $\cdot$ Ethics $\cdot$ Neoliberalism $\cdot$ New technologies $\cdot$ Racism $\cdot$ Ubuntucurrere

The Covid-19 pandemic has radically changed human lives across the globe. The pandemic has manifested as a multifaceted crisis: health systems of many countries have been found wanting, resulting in deaths; the global economy has plummeted into recession; governments have curtailed freedoms of citizens; and communities have closed schools and higher education institutions during lockdown periods.

As a society, we often raise critical questions in times of crises-old questions and new ones. Asking the perennial existential question of how we ought to live is apposite at this

Lesley Le Grange

llg@sun.ac.za

1 Department of Curriculum Studies, Faculty of Education, Stellenbosch University, Private Bag X1,

Matieland, Stellenbosch 7602, South Africa 
time. And also, the enduring curriculum question, first raised by Herbert Spencer (1884): What knowledge is of most worth? Other education questions that we could invoke are: How ought we to teach/learn? What are the prospects for education during and after the Covid-19 pandemic? What is education for in troubled times? Is knowledge enough? We are witnessing emerging responses to these questions, and I shall touch on these questions in various ways in this article.

For the most recent International Handbook of Curriculum Research, Pinar (2014) commissioned four introductory chapters to challenge accounts on curriculum studies presented by authors from different nations. In the first chapter, Autio (2014) highlights the moral dimension of education and makes the point that it is education's implicit morality that makes it educative. Autio's use of "morality" is not meant in a didactive sense but is more akin to ethics: a commitment to engage, in an ongoing basis, with the worthiness of knowledge - that is, with the worthiness of what education programmes include and/or exclude. According to Pinar (2014, p. 2), it is this sense of the moral that informs our "profession's ethics, our commitment to study, and teach as we engage in academic research to understand curriculum". Moreover, it also involves understanding curriculum as a complicated conversation that occurs among scholars of the field and between scholars and students.

In the second chapter, McCarthy, Bulut, and Patel (2014) discuss the reconfiguration of power that globalization accelerates, with a particular focus on race. They point out that race cannot be viewed in isolation but needs to be understood in contemporary times as structured through contradictory processes of globalisation, localisation, migration, and technologies of surveillance. The technologies of surveillance that the authors refer to are biometric technologies of information: face scanning; finger printing; DNA sampling; and so on. McCarthy et al. (2014) focus particularly on race, but their discussion can be extrapolated to other forms of discriminations that globalizations and new technologies hasten or reconfigure.

In the third chapter, Smith (2014) assesses the influence of neoliberalism on education, which includes, among other things, privatization, standardized assessments, and the use of technologies to make teaching/learning more efficient. He asks a pertinent question: how might we reimagine education given that neoliberalism brings into question the very assumptions that education is based on? Smith (2014) suggests that we need to analyze and interrogate neoliberalism on an ongoing basis in order to work through it, and that the inspiration for this ongoing examination could be drawn from the wisdom traditions, be they indigenous, religious, or philosophical.

In chapter 4, Wang (2014) focuses on nonviolence, which she explicates as an embodied sense of interconnectedness among humans, affirming compassion and a positive affiliation with others - in other words, our common humanity. She finds support for her argument from several philosophical, religious, and ethical traditions, including the African notion of Ubuntu, the Chinese notion of Tao, and indigenous peace-making traditions in North America.

In this article, I use the ideas articulated in these four chapters as a broad frame for advancing my thoughts. Accordingly, I divide the rest of the article into the following sections: the moral dimension of education; race, technologies of surveillance, and bio-informationism; neoliberalism and the prospects of education after the Covid-19 pandemic; and why we need Ubuntu-currere. Although my focus here is on the scholarly field of curriculum studies, I do at times explore implications for the school curriculum. When referring to the school curriculum, I make reference to the school subject that I know best, school biology. 


\section{The moral dimension of education}

Education is by definition a moral enterprise, but the Covid-19 pandemic has given rise to particular moral dilemmas for all people involved in education. Governments had to make decisions on school closings and also on when to reopen them. These are not easy decisions, and neither are the consequent choices that those impacted have had to make. In South Africa, schools are more than places where knowledge is exchanged between teacher and learner. For children from vulnerable communities, they are also places of safety and security: among other things, more than 9 million children receive 2 meals per day at school as part of the National School Nutrition Programme (NSNP). But during the lockdown period and level 4 of the government's risk-adjusted approach, the NSNP was temporarily suspended. This left these children at risk of being underfed and/or malnourished during periods of school closures.

Gontsana (2020) reports that during the lockdown period the government of the Western Cape, one of the nine provinces in South Africa, made emergency funding available to provide meals to children in vulnerable communities. (The Western Cape is the only province not governed by the ruling party, the African National Congress [ANC]. It is governed by the nation's official opposition, the Democratic Alliance [DA].) Thus, some schools opened their gates, arranged for learners to sit in open fields at a distance from one another, and gave them meals. However, the country's largest teachers union, the South African Democratic Teachers Union (SADTU), opposed this action. SADTU is affiliated to the Congress of South African Trade Unions, which, together with the South African Communist Party, is in a tripartite alliance with the ANC. SADTU stated that the DA was going against the president's plans to curb the spread of the virus, and although the union was concerned about the welfare of working-class learners and their families, it was opposed to learners being given meals on the school grounds because this would place them and their communities at increased risk. In this instance, one might argue that two entities with different political motives were using learners as a political football. The teacher in this situation is faced with a difficult moral dilemma. Assuming that the teacher is a member of SADTU and is also acutely aware that learners are not receiving adequate nutrition during the lockdown period, does the teacher support his/her union or does the teacher assist with feeding learners at the school?

At the time of writing this article, the South African minister of basic education announced a phased reopening of schools. Learners who returned to schools first were those at the exit points of primary and high schools-grades 7 and 12 learners, respectively. This happened in June 2020, which was the beginning of winter in the Southern Hemisphere, and the disease was predicted to peak in South Africa around August/September 2020. Thus, learners returned to schools at arguably the most vulnerable time for them in terms of the spread of the pandemic. The government has said that parents can decide themselves whether to allow their children to return to school or to do home schooling. This is a difficult moral decision for any parent to make. It is an even more difficult decision for poor and working-class families, who do not have the facilities and capacity to support their children to do home schooling and who may need to find childcare if they have to return to work themselves. Role players in education have only difficult choices, as these two instances illustrate. And decisions of this kind might best be left to parents, free of coercion. But what should the response of scholars who engage in the study of curriculum be at this time? What is their moral obligation during the Covid-19 pandemic? 
Autio (2014) refers to the sense of "moral" as a "professional ethics" that relates to our commitment to study, teach, and engage in academic research aimed at understanding curriculum. During the Covid-19 pandemic, though we might be isolated and unable to engage with one another through traditional face-to-face means, our commitment to study, teach, and engage in academic research should not weaken. In fact, at this time we need a deeper commitment to this sense of ethics. This means that we should use new technologies to engage in complicated conversations about curriculum-related matters. As with many other conferences, the 2020 annual conference of the South African Education Research Association (SAERA) was cancelled, but members have been encouraged to engage with one another through their special interest groups (SIGS), facilitated through use of technology. Members of the Curriculum Studies SIG, for example, have had complex conversations about the curriculum challenges facing South Africa during and after the Covid-19 pandemic. The SIG released a statement that invites a broader audience to take part in such ongoing discussions. These conversations have not been chitchats of the kind Aoki (2004) cautions against, nor have they been simple exchanges of information; instead, they have been robust, often involving disagreement, but always with a sense of mutual belonging and a commitment to the intellectual life of the field. I have been privileged to enjoy such exchanges in transnational spaces, in the way in which Pinar (2006, p. 178) suggests that such spaces can be productive. He points out that, in transnational spaces, scholars of the field should distance themselves from their own national cultures and politics, and listen respectfully to others, thus creating "a global public space for dissension, debate, and on occasion solidarity". At this time, we need such often-difficult conversations to intensify - we do not need social distancing but social solidarity in national and transnational spaces that new technologies and the commitment of curriculum scholars make possible. In other words, we need physical distancing, not social distancing.

Again, with reference to the moral dimension of education, Autio (2014) also refers to the need for conversations and debates on the worthiness of knowledge. That is, we need to ask critical questions about what knowledge is of most worth when it comes to the school curriculum during and after the Covid-19 pandemic. Here, I turn to school biology as an example. Since its inception, a feature of school biology has been the debate on whether it is a "science of life" or a "science of living" (Le Grange 2008). Few would disagree that school biology has to include both of these dimensions, but the pendulum has swung back and forth over the years concerning where we should place the emphasis. From the last half of the twentieth century to the twenty-first century, school biology has been largely characterized by the force-feeding of learners of a diet of "theory", regurgitated on tests and examinations - content is often irrelevant to the needs of learners or of society. In other words, during that time schools have emphasized biology as a "science of life" (Le Grange 2008). Less than $2 \%$ of South African school leavers continue with careers in biology-related fields. Therefore, for the majority of learners who take biology at school, the current subject content is largely unrelated to their lives. This is true despite its potential relevance to many contemporary issues facing society; among them, human diseases, including virus-causing diseases such as Covid-19; human trafficking involving the sale of body parts; biodiversity loss; commodification of the genetic code; threats of biological warfare. Instead of traditional unifying themes such as "structure and function" or "evolution", the curriculum could revolve around more relevant themes, such as sustainability, for example. Such themes also reinforce connections between many other school subjects. Here, the notion of sustainability does not have to do with policy goals but with cultivating a frame of mind that enables lifelong learning. 
To continue with sustainability as an example, using it as a unifying theme in biology classrooms could prove to be productive. Instead of learners studying animals only in relation to themes such as structure and function, they could investigate what sustains an animal in fulfilling its ecological role, or occupying its niche, for example. It involves a way of getting learners to think about biology differently, to develop frames of mind focused on sustainability. Bonnett (2003, p. 683) avers that a frame of mind is a "general mode of engagement with the world through which the world as a whole is revealed to us. ... [I]t is more or less a conscious way of being in the world". This requires a specific cognitive/ conceptual outlook - but also involves our sensing of things and encapsulates the affective, moral, aesthetic, imaginative, and other receptions and responses that Bonnett (2003, p. 684) refers to as "a mode of sensibility". It is a mode of sensibility toward sustainability that might be cultivated in biology classrooms after the Covid-19 pandemic. Not as a quick fix but as a habit of mind that might develop over time as the world of biology is "revealed" to learners through a conscious focus on sustainability.

\section{Race, technologies of surveillance, and bioinformationism}

In their chapter, McCarthy et al. (2014) challenge scholars of curriculum to take seriously the reconfiguration of power as globalization quickens, and in particular how technologies of surveillance - such as biometric technologies, face scanning, finger printing, DNA sampling, etc. - can be used to advance or sustain racism. Subtle forms of racism might emerge as technologies of surveillance are used after the Covid-19 pandemic, because these technologies provide fertile ground for racism's growth and consolidation. The pandemic will probably accelerate racism and other forms of discrimination, for several reasons-and there is already evidence of this. But the Covid-19 pandemic has also exposed the underbelly of racial inequalities in such countries as the US, the UK, and South Africa.

Devakumar, Shannon, Bhopal, and Abubakar (2020) point out that outbreaks such as Covid-19 create fear, and that fear is the key ingredient for racism and xenophobia to flourish. They go on to say that the pandemic has exposed the social and political fractures within communities, with racialized responses, that have affected marginalized groups disproportionately. Devakumar et al. (2020) note that we have already witnessed microaggressions or overt violence targeting Chinese people and barring them from establishments. Moreover, political leaders have exploited the Covid-19 pandemic to buttress racial discrimination by hardening border polices and conflating public health curtailments with anti-migrant rhetoric. For example, Italy's Prime Minister cynically linked the Covid-19 pandemic to African asylum seekers, and the US President referred to SARS-CoV-2 as "the China virus" (Devakumar et al. 2020). These developments create fertile ground for racism, which is now also advanced through the technologies of surveillance that McCarthy et al. (2014) identify. The advances in technologies accelerated by Covid-19—and the powers that governments have to subject citizens, and particularly foreign nationals, to a range of tests under the guise of protecting public health interests - could be further aiding and abetting this situation.

The Covid-19 pandemic has also laid bare racial inequalities in the US, UK, and South Africa. In the US, the death rate among African Americans is three times that of white Americans because of poor living conditions, poor nutrition, lack of access to healthcare facilities, and comorbidities (Begley 2020). Moreover, African Americans are also bearing the brunt of the devastating economic impact of the Covid-19 pandemic (Rodgers 2020). We have also observed this disproportionate negative effect of the Covid-19 pandemic on black and Asian 
people in the UK. Andrews (2000) points out that this should not surprise us, and that it is a mistake to look at these racial differences through the lens of biology, because the issue is not a genetic but a social one. It is the consequence of sustained discrimination at systemic levels - economic, political, and social. In South Africa, this pandemic has revealed the extent of the country's gross inequalities. Recent statistics show that 20 million South Africans do not have reliable access to running water in their homes (Ellis 2020); the government had to deliver thousands of water tanks to communities in a desperate attempt to slow the spread of the virus. And in the informal settlements where millions of black South Africans live, social distancing is a near impossibility. These vulnerable South African communities are also likely to bear the brunt of the economic impact of the pandemic.

McCarthy et al. (2014) have reminded us of the importance of bringing race-and its reconfiguration as globalization accelerates-into our curriculum conversations and actions. Race and racism-if they are currently blind spots or blank spots in our work-need to become key concerns in educational arenas. According to Wagner (1993), blank spots are what scientists know enough about to question but do not know how to answer, and blind spots are what they don't care about or know enough about. To return for a moment to school biology: When it emphasizes a "science of life" approach, then race becomes a genetic topic and the conclusion is that there is only one human race, one species, Homo Sapiens. However, this approach can create a blind spot to race as a social construct and its sustained negative impact on people of colour across the globe. And it is this blind spot that has also made race science endure for more than a century and why we are seeing its growth in contemporary times (for more details, see Le Grange 2019a). If school biology is to address issues related to race, then an emphasis on a "science of living" approach is more apposite than a "science of life" approach.

Lastly in this section, I shall turn briefly to the issue of bioinformationalism. Bioinformationalism relates to parallels between the propagation of fake news in social media echo chambers, and the evolution and transmission of infectious diseases (Peters, McLaren, and Jandrić 2020). Peters et al. (2020) point out that the Covid-19 pandemic is the first instance in which a biological virus has become dialectically intertwined with nonbiological viral information. What the authors are suggesting is that a biological virus and nonbiological viral information are working in tandem to accelerate the spread the virus. In other words, when fake news about the pandemic goes viral—such as "Covid-19 does not affect Africans" (a myth circulated across the African continent [Padayachee and Du Toit 2020]) - it influences peoples' behaviour in a manner that results in the spreading of the biological virus. And when the viral spread of fake news has racial connotations, such as linking the biological virus to African asylum seekers, then it also spreads racism. The coterminous nature of biological and nonbiological-information viruses adds to the complexity of issues related to the reconfiguration of race that globalization quickens and, consequently, to the complexity of curriculum scholars' work. To return to school biology for the moment: the imbrication of biological viruses and the viral spread of nonbiological information could certainly be a topic for inclusion in school biology classroom conversations, and learners could be asked to generate as many similarities and differences between biological viruses and nonbiological viruses generated through ITCs as possible. 


\section{Neoliberalism and the prospects of education after the Covid-19 pandemic}

In his chapter, Smith (2014) reminds curriculum scholars of the pervasiveness of neoliberalism in education and emphasizes the need to analyze neoliberalism and its effects on an ongoing basis. Neoliberalism can be traced back to seventeenth-century liberal perspectives, which became marginalized as a result of the rise of welfare-state liberalism (late nineteenth century) and Keynesian economics (twentieth century). The revival of neoliberalism in the late twentieth century is associated with the emergence of the new right in Europe and the US, often referred to as "Thatcherism" and "Reaganism" after two of its key proponents (Le Grange 2006). Although neoliberalism has different strands, all neoliberals embrace the following three basic principles: a commitment to individual liberty and a reduced state; a shift in policy and ideology against government intervention; and a belief that market forces should be allowed to be self-regulating (for a comprehensive discussion on the ascendancy of neoliberalism, see Olssen, Codd, and O'Neill 2004).

Many Western governments floundered when Covid-19 resulted in a global pandemic because their health systems were unable to cope with the pandemic's demands. Governments found themselves in a precarious position because of their underspending on healthcare-consequent on adopting neoliberal policies. Moreover, some scholars have gone as far as to link an increase in relatively unknown and highly infectious viruses to neoliberal capitalism. As McKinley (2020) writes:

[T]he increased occurrence of largely unknown and ever-more-virulent viruses is directly linked to the nature/character of land use and food production under the neoliberal model of capitalism; to the contemporary dominance of an "industrial model" of agriculture that is umbilically tied to the never-ending search for maximum profits, whatever the human, social and/or environmental consequences.

Just as the Covid-19 pandemic as a public health crisis needs to be understood against the backdrop of neoliberalism, so, too, does the education crisis that has deepened during the pandemic in South Africa. In the late 1980s, the outgoing apartheid government of South Africa adopted neoliberal education policies and introduced new models for white schooling that involved the semi-privatization of these state schools under the guise of racially integrating them. The school model that survived into South Africa's democratic dispensation was the model-C school; today, many elite and middle-class public schools in South Africa are commonly referred to as "former model-C schools". At their inception, the model-C schools were fee-paying schools, and they were allowed to sell excess land, which enabled them to accumulate capital. These resources enabled these schools to appoint additional teachers to their staffs and, by doing so, improve the quality of education provided. After 1994, South Africa's democratically elected government continued the neoliberal trend and maintained what has become a grossly unequal public school system. The government's attempts to make the schools in economically poor communities non-fee paying-by dividing them into different quintiles-have done little to arrest the inequalities that characterize the South African schooling landscape (see Le Grange, Reddy, and Beets 2012).

When South Africa went into lockdown during the pandemic and closed its schools, the unequal education system in South Africa was exposed even further. Learners in private schools as well as in affluent and middle-class public schools migrated relatively easily to emergency remote learning, because these learners had access to devices and connectivity, 
as well as support from teachers and parents. Access to any form of online learning for the majority of school learners remains a pipedream; thus, the Covid-19 pandemic has likewise laid bare the severity of the digital divide in South Africa (Davids 2020). Moreover, when schools reopen as the country moves to lower levels of its risk-adjusted approach, learners who attend schools in economically poor communities will be at greater health risk. Such schools lack basic sanitation and water infrastructure; moreover, their inferior facilities will make physical distancing a challenge. Although learners in South Africa's bimodal schooling system have the same explicit curriculum, the curriculum-as-lived by the two sets of learners is radically different. The Covid-19 pandemic will further reduce the life chances of a learner from a school in an economically poor community relative to those of a learner in a private or affluent public school.

Additionally, as affluent and middle-class schools pivot toward online learning and governments invest in technology infrastructure to make online learning more widely available after the Covid-19 pandemic, we must be aware of the dangers regarding these developments in the context of neoliberal capitalism. It is my contention that we should view new technologies (and in the context of education, online teaching/learning) dialectically. In other words, we need to recognize both their productive potential to advance the goals of social justice and the dangers of their consolidating inequities. In the context of neoliberal capitalism, not only will the digital divide widen, as noted, but also the migration to online learning could result in greater privatization of schooling as for-profit intermediaries become involved in developing online programmes/courses. This is because public schools do not have the capacity to develop such programmes or courses-platform pedagogy morphs into platform capitalism (for a more detailed discussion on such developments, see Hall 2016; Le Grange 2020). In this context, instrumentalist approaches to education would thrive and policy makers would cement standardized tests to improve efficiencies. Performativity regimes-including surveillance of both teachers and learners-are likely to increase.

If there is a lesson to be learned from the Covid-19 pandemic, it is that communities in South Africa radically reconfigure and resource their schools. Such a reconfiguration needs to make those who inhabit schools (learners and teachers) the central concern, and to open up the pathways for the becoming of their lives (in relationship with one another). It is with this in mind that I turn to a discussion of the notion of Ubuntu-currere.

\section{Why we need Ubuntu-currere}

The Covid-19 pandemic will probably not be the last global crisis facing humanity in the twenty-first century. If another virulent virus is not the cause of such crisis, then the cause could be an environmental catastrophe-that is, if humanity continues on its unsustainable course and neoliberal capitalism continues to thrive. It is sobering to note that global crises have not led to the weakening of neoliberal capitalism, as evident in the case of the 2008/2009 financial crisis. Hall (2016) points out that it was not surprising that Uber and Airbnb had their genesis during that financial crisis, in the years 2008 and 2009, respectively. These for-profit, "sharing"-economy, platform-based companies have taken neoliberalism to an ideal form. Customers benefit from the services offered, but, for the on-demand worker in these industries, rights and benefits have become eroded as these businesses escape state regulation (see Hall 2016; Le Grange 2020). And so, there is a 
danger that, in the wake of the current pandemic, we might see greater privatization of several sectors, including healthcare and education.

Smith (2014), in his chapter, averred that, to get beyond neoliberalism, we need to analyze it on an ongoing basis. He goes on to say that in our critical engagement with neoliberalism we might find inspiration in wisdom traditions, be they indigenous, religious, or philosophical. It is this part of Smith's chapter that connects to Wang's (2014) - the fourth introductory chapter in Pinar's (2014) edited handbook-where she promotes nonviolence through the invocation of indigenous and peace-making traditions such as the African notion of Ubuntu and the Chinese notion of Tao. Given the violence perpetrated against humans (particularly those on the margins of societies) that the Covid-19 pandemic has laid bare, we could find inspiration from the traditions that Wang (2014) refers to. Therefore, following on from Smith (2014) and Wang (2014), I propose that the notion of Ubuntu-currere might provide the inspiration and motive force for ridding ourselves of the shackles of neoliberal capitalism and its effects on education.

I invoked the idea of Ubuntu-currere in a keynote address at the fifth triennial conference of the International Association for the Advancement of Curriculum Studies (IAACS) (Le Grange 2015). The idea brings together insights from the African value of Ubuntu and William Pinar's (1975) autobiographical method currere, which was extended by Wallin (2010). Ubuntu, derived from aphorisms in the Nguni languages of southern Africa, means that our being and becoming is dependent on others. In contrast to Descartes's cogito ergo sum, "I think, therefore I am", Ubuntu means "because we are, therefore I am". Some have misconstrued the meaning of Ubuntu, arguing that it is, by definition, speciesist. However, what we need to understand is that relationality between humans (Ubuntu) is emblematic of the relatedness of all things in the cosmos. I point out that Ubuntu is the concrete expression of the Shona concept Ukama, which mean relatedness of all things in the cosmos (Le Grange 2012). In other words, Ubuntu is a microcosm of Ukama. Moreover, Ramose (2009) has argued that Ubuntu is antihumanist and involves the ongoing unfolding of the human in relationship with the other-that the human being is in-becoming.

Forty-five years ago, Pinar (1975) first invoked the etymological root of "curriculum": the Latin currere, "to run the course". In doing so, he refocused curriculum on the significance of individual experience, "whatever the course content or alignment with society or the economy" (Pinar 2011, p. xii). Currere privileges the individual and Pinar (2011, p. 2) argues that it is a complicated concept, because each of us is different in our genetic makeup, our upbringings, our families, and, more broadly, our race, gender, class, and so on. Put simply, currere shifts the attention away from the concept of a predetermined course to run, to a focus on how the course is run by each individual, given each one's unique makeup, context, hopes, aspirations, and interactions "with other human beings and the more-than-human world" (Le Grange 2019b, pp. 221-22). In other words, each person has her or his own life story, and the understanding of one's own story through academic study is at the heart of curriculum. Pinar (1975) develops currere as an autobiographical method with four steps or moments-regressive, progressive, analytical, and syntheticalthat depict both temporal and reflective moments for autobiographical research of educational experience.

Both Ubuntu and currere affirm the importance of human experience-the being and becoming human-and the unfolding of the human as the world is revealed to it. But Le Grange $(2015,2019 b)$ brings the two notions together to shift the emphasis from the individual to a subject that is ecological — a subject that is embodied, embedded, and enacted. I invigorated lines of connections between emerging (post)human theories to create a new concept: Ubuntu-currere. I wrote: 
Ubuntu-currere shifts our registers of reference away from the individual human being to an assemblage of human-human-nature. In other words, subjectivity is ecological. Moreover, the subject is always in becoming and the becoming of a pedagogical life is relational-the subject becomes in relation to other humans and the more-than-human-world. The notion in-becoming ensures that the human cannot be defined nor have fixity and therefore Ubuntu-currere is anti-humanist. Put differently, Ubuntu-currere negates the construction of a molar identity that is a screen against which anything different is othered in a negative sense. Ubuntu-currere has resonance with new materialist post-human theory in that it embraces an ontology of immanence - that there is a material immanent plane that connects everything in the cosmos and from which all actualised forms unfold/become. Ubuntu-currere opens up multiple coursings for developing post-human sensibilities driven by the positive power of potentia that connects, expresses desire and sustains life. ... But, it also makes possible conversations with the more-than-human so that we can listen to the rhythm and heartbeat of the earth-so that our conversations do not happen on the earth but are bent by the earth. (Le Grange 2019b, pp. 221-222; italics in original)

Ubuntu-currere affirms the importance of caring for other humans beings_- "humanness" does not mean humanism and is antithetical to it. The subject of education informed by Ubuntu-currere is not egoistic and holds no ontological privilege, but is placed on an immanent plane with all living beings. The actions (ethics) of this subject in the world are to release the power that is within-in contrast to the power that imposes or acts upon the other. This power of potentia is within all life and connects all modes of life. It is this same power that we see when humans perform generous acts of caring for others during the Covid-19 pandemic, when they unselfishly give up their lives to save or feed another. This power is counter to the negative power of postestas that imposes, that engages in othering, that colonizes, that controls, etc. If we are to have a different post-Covid-19 world, then its actualization depends on invigorating potentia. Education informed by Ubuntucurrere involves supporting learners to release potentia so that actions in the world are about enhancing life.

\section{Concluding thoughts}

The ideas advanced in the four introductory chapters of the International Handbook of Curriculum Research that frame this article are connected to one another and crystalize in the notion of Ubuntu-currere. The moral dimension of education speaks to our sense of belonging to something bigger than our individual selves and the need for our ongoing commitment to engage in complicated conversations with one another, and more so in troubled times. And in such conversations, we should understand and investigate how the ongoing discriminations of all kinds that continue to plague us are amplified and accelerated. The Covid-19 pandemic has laid bare how those on the margins of society bear the brunt of the pandemic - and that the underlying cause of much of this reality of inequality is the dominance of neoliberal capitalism. If we are to avoid the damaging effects of crises such as the current one, then we need perform currere to free ourselves from the fetters of neoliberal capitalism. And if we are to live in harmony with one another and the more/other-than-human world, then we need to fuse currere with Ubuntu. Ubuntucurrere makes possible an education that is a life-long affair of experimentation with the 
real-experimentation constrained only by life itself. Put differently, our experimentation with life should be curtailed only when we hurt other humans or the more/other-thanhuman world.

\section{References}

Andrews, K. (2000, May 11). Under Covid-19, racism in Britain and the world is a matter of life and death. Daily Maverick. https://www.dailymaverick.co.za/article/2020-05-11-under-covid-19-racism-in-brita in-and-the-world-is-a-matter-of-life-and-death/.

Aoki, T. T. (2004). Layered understanding of orientations in social studies program evaluation. In W. F. Pinar \& R. L. Irwin (Eds.), Curriculum in a new key: The collected works of Ted T. Aoki (pp. 168186). Mahwah, NJ: Lawrence Erlbaum Associates.

Autio, T. (2014). The internationalization of curriculum research. In W. F. Pinar (Ed.), International handbook of curriculum research (2nd ed., pp. 17-31). New York, NY: Taylor \& Francis.

Begley, S. (2020, June 15). To understand who's dying of Covid-19, look to social factors like race more than pre-existing diseases. STAT. https://www.statnews.com/2020/06/15/whos-dying-of-covid19-lookto-social-factors-like-race/.

Bonnett, M. (2003). Education for sustainable development: Sustainability as a frame of mind. Journal of Philosophy of Education, 37(4), 675-690.

Davids, N. (2020, March 7). Maybe the coronavirus will set SA on a path to a more equitable education system. News24. https://m.news24.com/Columnists/GuestColumn/opinion-maybe-the-coronavirus-willset-south-africa-on-the-path-to-a-more-equitable-education-system-20200327.

Devakumar, D., Shannon, G., Bhopal, S. S., \& Abubakar, I. (2020). Racism and discrimination in Covid-19 responses. The Lancet, 395(10231), 1194. https://doi.org/10.1016/S0140-6736(20)30792-3.

Ellis, E. (2020, May 14). Covid-19: Exposing a water crisis in the making. Daily Maverick. https://www. dailymaverick.co.za/article/2020-05-14-covid-19-exposing-a-water-crisis-in-the-making/.

Gontsana, M.A. (2020, April 9). Lockdown: School feeding scheme reopens in Western Cape to assist "desperate communities". News24. https://www.news24.com/SouthAfrica/News/lockdown-school-feedingscheme-reopens-in-western-cape-to-assist-desperate-communities-20200409.

Hall, G. (2016). The uberfication of the university. Minneapolis, MN: University of Minnesota Press.

Le Grange, L. (2006). Quality assurance in South Africa: A reply to John Mammen. South African Journal of Higher Education, 20(6), 903-909.

Le Grange, L. (2008). The history of biology as a school subject and developments in the subject in contemporary South Africa. Southern African Review of Education, 14(3), 89-105.

Le Grange, L. (2012). Ubuntu, ukama, environment and moral education. Journal of Moral Education, 41(3), 329-340.

Le Grange, L. (2015). Currere's active force and the concept of Ubuntu. Keynote address delivered at the 5th triennial conference of the International Association for the Advancement of Curriculum Studies. University of Ottawa, 26-30 May.

Le Grange, L. (2019a). A comment on criticisms of the article "Age- and education-related effects on cognitive functioning in Colored South African women". South African Journal of Higher Education, 33(4), 9-19.

Le Grange, L. (2019b). Currere's active force and the concept of Ubuntu. In C. Hébert, N. Ng-A-Fook, A. Ibrahim, \& B. Smith (Eds.), Internationalizing curriculum studies: Histories, environments, and critiques (pp. 207-226). New York, NY: Palgrave MacMillan.

Le Grange, L. (2020). Could the Covid-19 pandemic accelerate the uberfication of the university? South African Journal of Education, 34(4), 1-10.

Le Grange, L., Reddy, C., \& Beets, P. (2012). Socially critical education for a sustainable Stellenbosch by 2030. In M. Swilling, B. Sebitosi, \& R. Loots (Eds.), Sustainable Stellenbosch: Opening dialogues (pp. 310-321). Stellenbosch: African Sun Media.

McCarthy, C., Bulut, E., \& Patel, R. (2014). Race and education in the age of digital capitalism. In W. F. Pinar (Ed.), International handbook of curriculum research (2nd ed., pp. 32-44). New York, NY: Taylor \& Francis.

McKinley, D. (2020, March 24). Coronavirus and capitalism: Structural foundations and opportunities for systemic change. Daily Maverick. https://www.dailymaverick.co.za/opinionista/2020-03-24-_trash ed-2/. 
Olssen, M., Codd, J., \& O’Neill, A. (2004). Education policy: Globalization, citizenship and democracy. London: Sage.

Padayachee, N., \& Du Toit, L. C. (2020, April 15). Debunking nine common Covid-19 myths doing the rounds in Africa: Some of the false claims being made about the coronavirus are harmless. Others can be potentially dangerous. Timeslive. https:/www.timeslive.co.za/sunday-times/lifestyle/health-andsex/2020-04-15-debunking-nine-common-covid-19-myths-doing-the-rounds-in-africa/.

Peters, M. A., McLaren, P., \& Jandrić, P. (2020). A viral theory of post-truth. Educational Philosophy and Theory. https://doi.org/10.1080/00131857.2020.1750090.

Pinar, W. F. (1975). The method of currere. Paper presented at the annual meeting of the American Educational Research Association (AERA). Washington, DC. https://files.eric.ed.gov/fulltext/ED104766.pdf.

Pinar, W. F. (2006). The synoptic text today and other essays. New York, NY: Peter Lang.

Pinar, W. F. (2011). The character of curriculum studies: Bildung, currere and the recurring question of the subject. New York, NY: Palgrave Macmillan.

Pinar, W. F. (Ed.) (2014). International handbook of curriculum research (2nd ed.). New York, NY: Taylor $\&$ Francis.

Ramose, M. B. (2009). Ecology through Ubuntu. In M. F. Murove (Ed.), African ethics: An anthology of comparative and applied ethics (pp. 308-314). Pietermaritzburg: University of KwaZulu-Natal Press.

Rodgers, W. M. (2020, May 6). Black Americans bearing the brunt of coronavirus recession: This should come as no surprise. The Conversation. https://theconversation.com/black-americans-are-bearing-thebrunt-of-coronavirus-recession-this-should-come-as-no-surprise-137587.

Smith, G. (2014). Wisdom responses to globalisation. In W. F. Pinar (Ed.), International handbook of curriculum research (2nd ed., pp. 45-59). New York, NY: Taylor \& Francis.

Spencer, H. (1884). What knowledge is of most worth. Ann Arbor, MI: University of Michigan.

Wagner, J. (1993). Ignorance in educational research: Or, how can you not know that? Educational Researcher, 22(5), 15-23.

Wallin, J. J. (2010). A Deleuzian approach to curriculum: Essays on a pedagogical life. New York, NY: Palgrave Macmillan.

Wang, H. (2014). A nonviolent perspective on internationalising curriculum studies. In W. F. Pinar (Ed.), International handbook of curriculum research (2nd ed., pp. 67-76). New York, NY: Taylor \& Francis.

Publisher's Note Springer Nature remains neutral with regard to jurisdictional claims in published maps and institutional affiliations.

Lesley Le Grange is Distinguished Professor in the Faculty of Education at Stellenbosch University, South Africa. He is also Vice-President of the International Association for the Advancement of Curriculum Studies (IAACS), a Fellow of the Royal Society of Biology (UK), a member of the Academy of Science of South Africa, and rated as an internationally acclaimed researcher by the National Research Foundation in South Africa. He has published more than 200 articles and serves on editorial boards of nine peer-reviewed journals. He has delivered more than 170 academic presentations and is recipient of several academic awards and prizes; the most recent is the South African Education Research Association (SAERA) Honours Award (2019) for outstanding contribution to Educational Research in South Africa. 